\title{
Arrangement of Multistory Underground Parking Garages in Complex Engineering and Geological Environment
}

\author{
Olga Vladimirovna Trushko \\ Department of Constructing Mining Enterprises and Underground Structures, \\ Saint-Petersburg Mining University, \\ 21-st Line V.O., 2, Saint-Petersburg, 199106, Russia. \\ E-mail: Trushko_OV@pers.spmi.ru \\ Vladimir Leonidovich Trushko \\ Department of Mechanics, \\ Saint-Petersburg Mining University, \\ 21-st Line V.O., 2, Saint-Petersburg, 199106, Russia. \\ E-mail: trushko@spmi.ru \\ Petr Alexeevich Demenkov \\ Department of Constructing Mining Enterprises and Underground Structures, \\ Saint-Petersburg Mining University, \\ 21-st Line V.O., 2, Saint-Petersburg, 199106, Russia. \\ Corresponding author: p.a.demenkov@ mail.ru
}

(Received October 1, 2019; Accepted April 23, 2020)

\begin{abstract}
This article discusses possible variants of underground parking lot in complex engineering and geological environment of St Petersburg, namely: soil excavation in open pit and excavation with solid supports. These methods were analyzed with regard to reasonability for preset construction conditions. A series of predictions were performed using Plaxis 2D software, two variants were described in this article: excavation with the bottom elevation of $+0.560 \mathrm{~m}$ and excavation with the bottom elevation of $-2,500 \mathrm{~m}$ and adjacent building (at the distance of $2.5 \mathrm{~m}$ ). The formulated problems were solved using 2D models. The model was based on the Mohr-Coulomb theory which facilitated estimation of geotechnical environment in the vicinity of the construction. Predictions of retaining wall according to the two considered variants have demonstrated that maximum soil settlement near the excavation is $20 \mathrm{~mm}$ and the maximum additional settlement of building at the distance of $2 \mathrm{~m}$ from the excavation is $30 \mathrm{~mm}$, which in both cases corresponds to predetermined specifications.
\end{abstract}

Keywords- Construction activities, Underground parking garages, Specialized methods, Sheet piling, Complex engineering and geological conditions.

\section{Introduction}

In well-developed countries underground garages become more and more popular due to shortage of surface parking lots and increasing number of vehicles. Some megalopolises in Asia already include obligatory arrangement of underground garages according to certain regulations under all newly erected structures.

One of the deepest parking lots in Leiden, the Netherlands, is located at the depth of $22 \mathrm{~m}$, which corresponds to seven-story building. In Hangzhou, China, automatic 12-level parking lot was built at the depth of about $40 \mathrm{~m}$ for 200 vehicles. It is obvious that with the increase in the number of vehicles, underground parking lots will be located more and more deeply. The building of the 
International Journal of Mathematical, Engineering and Management Sciences

Vol. 5, No. 5, 897-912, 2020

https://doi.org/10.33889/IJMEMS.2020.5.5.069

faculty of civil engineering, University of Minnesota, has seven underground stories, it was built in 1983.

The lack of parking places is accompanied by numerous problems: narrowing of driveways due to rows of parked vehicles, decrease in traffic safety, damaged lawns, environmental impairment, and others. In historical sites the best solution is the arrangement of multilevel underground garages, since in this case the most reasonable use of underground space under erected or retrofitted structures is achieved.

Construction of underground garages is the most difficult in megalopolises with complex engineering and geological environment, such as St Petersburg.

Stabilization of weal soil was studied in Russia and other countries (Abelev and Tokin, 1988; Dalmatov, 1988; Ilichev et al., 2009; Gotman, 2011). Construction of buildings in complex engineering, geological and hydrogeological environment of St Petersburg was substantiated in numerous works by Dashko (Dashko et al., 2011; Dashko and Lange, 2015; Dashko and Lange, 2017).

Architectural beauty and impressiveness of St Petersburg was created by prominent architects of Russia and Europe. Many buildings in historical part of the city are architectural masterpieces having no analogues in the World, which requires provision of their preservation, delicate and safe adaptation to modern conditions. Many old buildings after more than 100 years are at such stage when numerous failures are accumulated during long lifetime. For instance, loadbearing structures can be destroyed (walls, roof, foundations), decorations of facade and interior furnishings, structures and buildings are totally deformed with crack formation.

In addition, during long lifetime of residential buildings, requirements to standards of living also varied which led to moral depreciation of old buildings. Elimination of factors of physical and moral deterioration occurs during major repair and retrofitting. Regarding cultural heritage sites, this is adaptation for modern use. Arrangement of underground garages is requested and justified action improving investment attractiveness and quality of living in central districts, this measure should provide areas of comfortable existence due to elimination of parking lots in yards and adjacent streets. Specialized methods of construction are applied in complex engineering and geological environment (Carayannis et al., 2017; Cherepovitsyn et al., 2017; Cherepovitsyn and Ilinova, 2018).

At present, sheet piling becomes especially important because it facilitates construction activities in constrained urban environment without damages to surrounding buildings and structures.

This article discusses construction of two-level underground garage for 785 vehicles in the historical center of St Petersburg.

Geological structure of the site to the depth of $47.20 \mathrm{~m}$ is comprised of modern quaternary deposits (QIV) presented by technogenic formations (tIV) -fill soils (Engineering Geological Element EGE1); glaciolacustrine deposits (lmIV) - loose silty sands (EGE-2), weakly peaty soils (EGE-3), silty sands of medium density (EGE-4), plastic clay sands (EGE-5), fine and dense sands (EGE-6), fluid loams with very soft interlayers (EGE-7), upper quaternary deposits (QIII) of glaciolacustrine genesis (lgIII) presented by fluid loams with very soft strip-like interlayers (EGE-8), very soft 
International Journal of Mathematical, Engineering and Management Sciences

Vol. 5, No. 5, 897-912, 2020

https://doi.org/10.33889/IJMEMS.2020.5.5.069

laminated loams (EGE-9), plastic clay sands, indistinctly laminated (EGE-10); soils of glacier genesis (gIII) presented by sandy clays (EGE-11), silty dense sands (EGE-12), plastic clay sands with solid interlayers (EGE-13), middle quaternary deposits (QIII) of glaciolacustrine genesis (lgII) presented by stiff loams with semisolid interlayers (EGE-14), deposits of glacier genesis (gII) presented by sandy clays with plastic interlayers (EGE-15).

Underground waters, confined to silty (EGE-4) and fine (EGE-6.1 and 6) sands, positioned lower, produce pressure due to overlapping clay soils. These waters are opened at the depths of 5.20-12.70 $\mathrm{m}$ (absolute level: $0.35--7.30 \mathrm{~m}$ ). Underground waters of this water bearing stratum are hydraulically connected forming potentiometric surface with free-flowing waters at the depth of 0.90-3.00 m (absolute level: 2.40-5.33 m). Delivery head is 3.80-10.40 m. Opened levels are close to average annual values.

Construction site according to Specifications SNiP 23-01-99 is referred to climatic region II, subregion II V.0. Absolute minimum temperature of ambient air is $-36^{\circ} \mathrm{C}$, absolute maximum is $+34^{\circ} \mathrm{C}$. Soil freezing depth is $1.49 \mathrm{~m}$.

All site area is surfaced by filling. Major portion of the area is asphalted. Absolute levels of site relief vary from $6.5 \mathrm{~m}$ to $5.3 \mathrm{~m}$, smoothly declining eastwards. Northern and western sites are occupied with 4-5 story residential brick buildings from early 1900 -s. The buildings were erected on rubble stone continuous subsurface foundation. Some buildings are characterized by significant deformations in the form of diagonal cracks. The buildings are in critical condition; their stability can be maintained by reinforcement of their foundations. Other part of the site was occupied by nonresidential 2-3 story buildings which were demolished. Parts of concrete foundations of these buildings remain on the site.

\section{Methods}

The project of multicompartment residential complex comprised of three buildings with integral rooms and underground garage is located on a site with the surface area of $26,085 \mathrm{~m}^{2}$. At present the site is free from buildings, the existing engineering service lines should be disassembled or removed. Three buildings of ordinary historic development without tenants are located adjacent to the site from the north: building 11, building 13, building 15, they should be retained and repaired. On this territory it is possible to perform complex retrofitting of quarters and construction of new buildings and structures, providing that there is conformity with specified number of stories and formation of construction front.

The residential complex (Figure 1) is characterized as follows: three residential buildings with the height of up to $27.0 \mathrm{~m}$, number of stories is 7 above ground and 1-2 underground (garage); 2D dimensions are as follows: two buildings $-16 \times 60 \mathrm{~m}$, the third building is of complex configuration with pile foundation, load per pile is $120-150 \mathrm{t}$, load per cluster of piles is more than $300 \mathrm{t}$, pile penetration is $25-30 \mathrm{~m}$ from ground surface.

The underground garage (Figure 2) located on the site under overall residential complex is characterized as follows: number of stories: 2 underground, depth: $8.0 \mathrm{~m}$, pile foundation, load per pile: $120-150 \mathrm{t}$, load per cluster of pile: more than $300 \mathrm{t}$, pile penetration: $25-30 \mathrm{~m}$ from ground surface. 
International Journal of Mathematical, Engineering and Management Sciences

Vol. 5, No. 5, 897-912, 2020

https://doi.org/10.33889/IJMEMS.2020.5.5.069

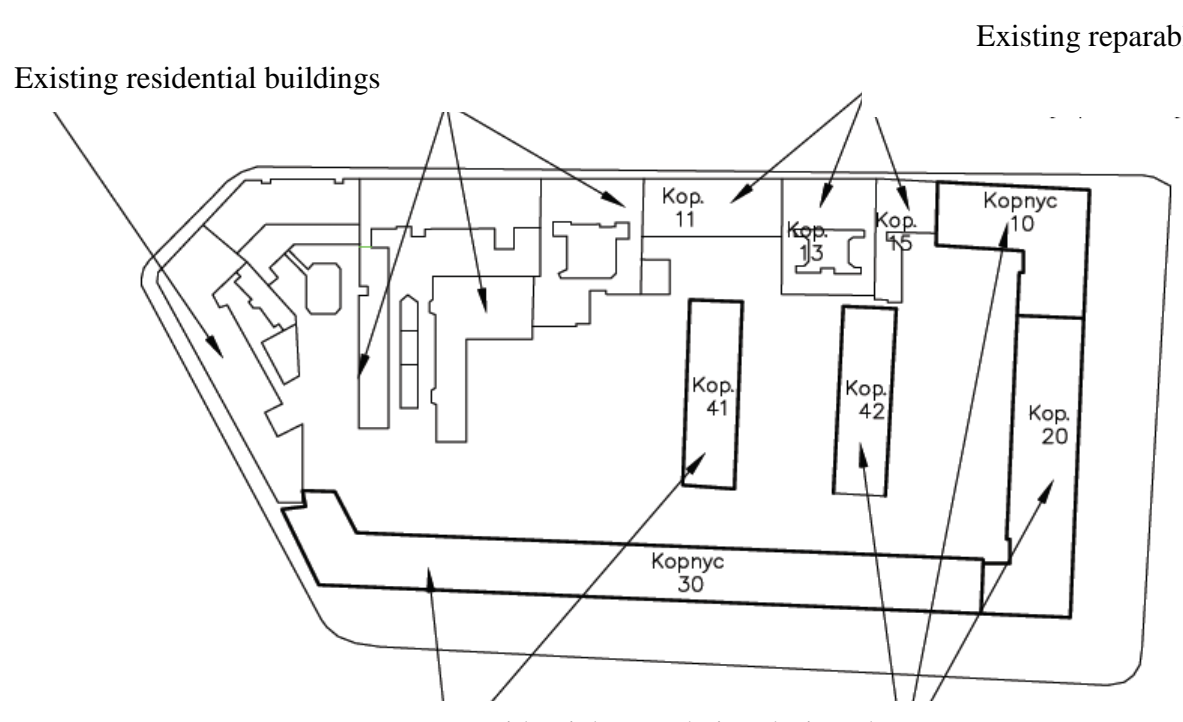

Residential estate being designed

Figure 1. Schematic view of residential estate

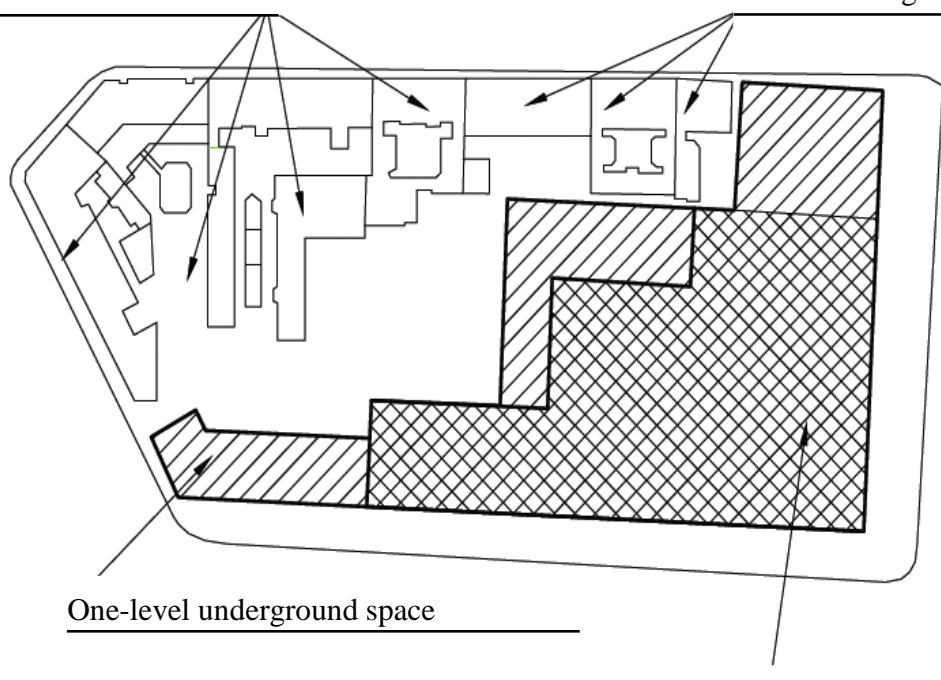

Two-level underground space

Figure 2. Schematic view of two-level underground garage 
International Journal of Mathematical, Engineering and Management Sciences

Vol. 5, No. 5, 897-912, 2020

https://doi.org/10.33889/IJMEMS.2020.5.5.069

Two main excavation variants are possible for arrangement of two-level underground garage: excavation in open pit and excavation with solid supports.

Taking into account the depth of foundation frame and preliminary arrangement, the design excavation depth is from 5.2 to $8.0 \mathrm{~m}$ (for one-level and two-level underground garage, respectively).

Excavation with solid supports or excavation by TOP-DOWN method assumes creation of single solid floor disc which provides excavation shoring. In this case it is supposed to arrange two floor discs at the covering levels of the first and the second story (or foundation frame in one-story parts of the garage). Excavation is carried out only after creation of respective support (floor disc).

Configuration of support takes into account geometry of facility, existence of above-ground rooms, technological openings for soil removal and for staircases and lifts, communications and engineering service networks, etc.

In the area of upper support, it is possible to construct integral supporting disc made of elements of steel concrete floor and metal spacers. Such combined floor structure facilitates creation of single supporting disc, as well as decreases complexity of vertical wall elements concentrated mainly in residential areas of the complex (Figure 3).

The advantages of this variant (TOP-DOWN) of arrangement of two-level underground facilities are as follows:

- Reliability of supporting systems;

- Unnecessary mounting of numerous temporal metal structures and interim sheet piling;

- Possibility of construction of above-ground structures of a certain building of the complex simultaneously with excavation.

The main disadvantages of the variant are as follows:

- Complicated designing.

- Significant increase in soil excavation costs.

- Complicated excavation of weak soils under steel concrete floors and, as a consequence, increases in excavation time.

- Necessity to arrange deformation joints in ready floor structures.

- Necessity to arrange temporal piles for accommodation of loads from floors.

Excavation with metal spacers is an open pit (erection of two-level underground facilities), that is, activities are carried out in open pit on individual sites.

In this case a possible sequence of excavation of two-level underground facility is as follows: at the first stage, two-level underground facility is arranged under protection of two levels of metal spacers in the first trench; at the second stage, the two-level underground facility is arranged in parallel trench. The produced elements of steel concrete structures are combined into single underground facility in the following sequence (Figure 4): inserted spacers between the elements of two underground facilities in sections are cut off at the length of 3-4 m; in working site/section, the elements of sheet piling are removed; free segment between two sections is covered with 
International Journal of Mathematical, Engineering and Management Sciences

Vol. 5, No. 5, 897-912, 2020

https://doi.org/10.33889/IJMEMS.2020.5.5.069

concrete; then the next section is processed where the described sequence of operations is repeated (Kazanin et al., 2019a, 2019b; Sidorenko et al., 2019).

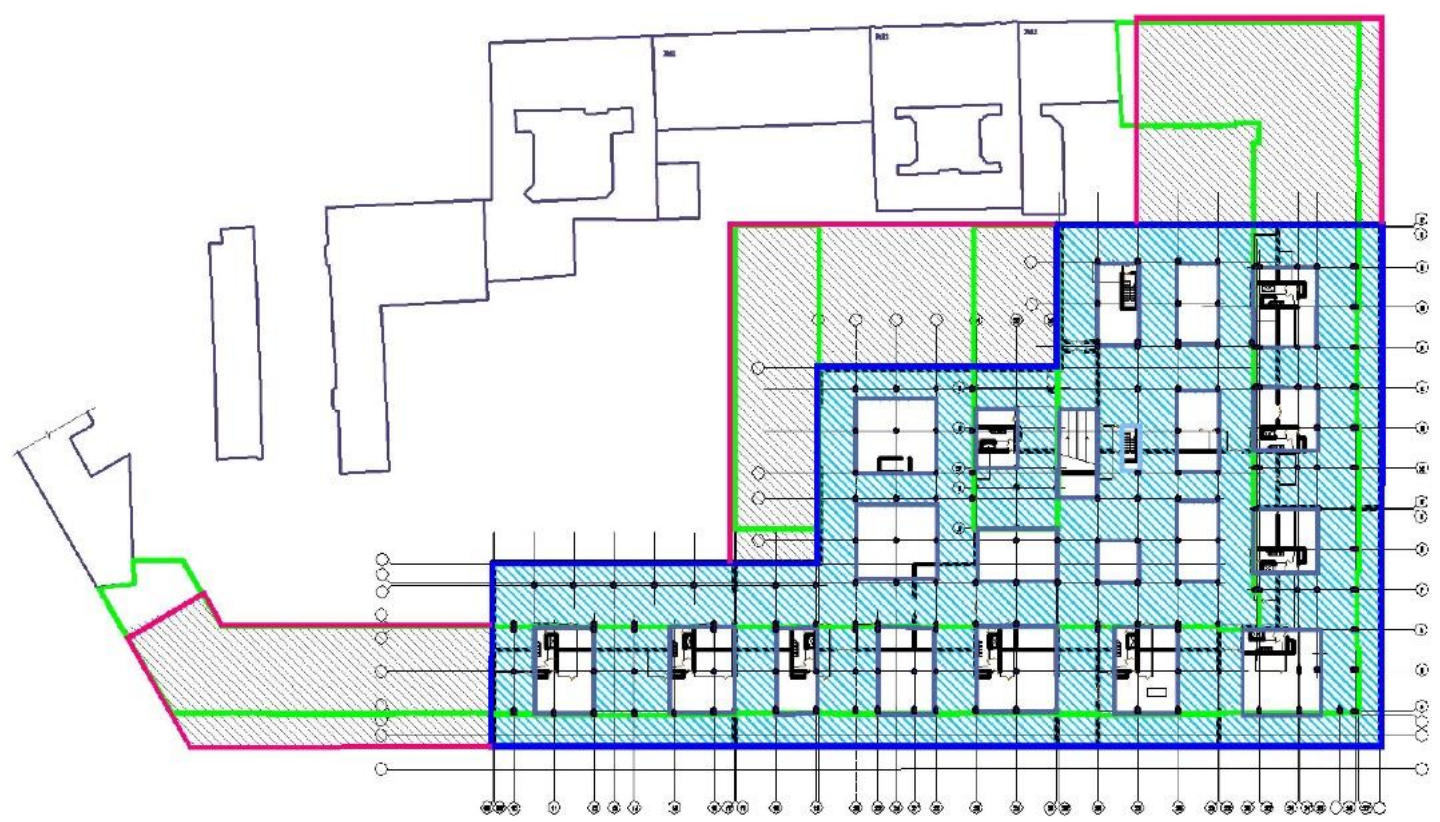

Figure 3. Arrangement of two-level underground rooms: monolithic reinforced concrete floor in the area of two-level underground structure at the bottom elevation of +1.81 and excavation of the second level to the target depth
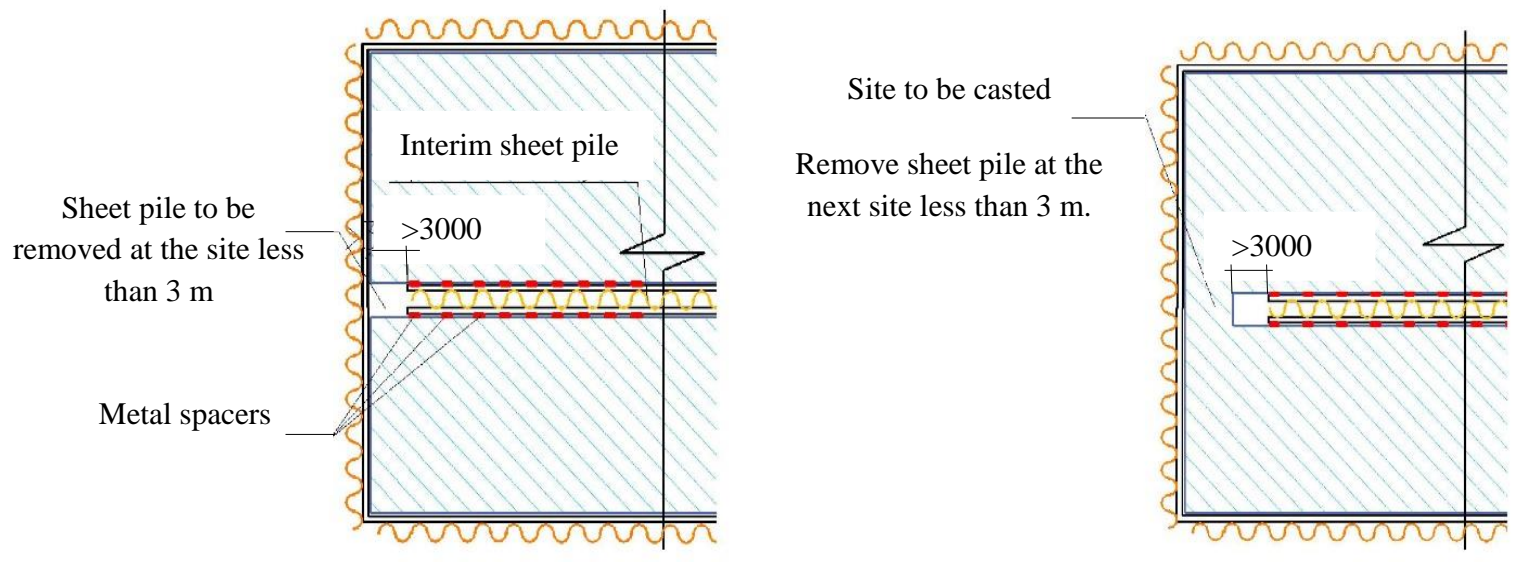

Figure 4. Schematic view of separate startup lines of two-level underground garages using metal spacers and temporal sheet pile 
International Journal of Mathematical, Engineering and Management Sciences

Vol. 5, No. 5, 897-912, 2020

https://doi.org/10.33889/IJMEMS.2020.5.5.069

The advantages of the variant of underground facilities using separate excavations are as follows:

- Possibility to perform excavation in required sequence;

- Reduced penses for soil excavation;

- Possibility to arrange deformation and temperature joints;

- Unnecessary soil excavation on large sites.

- Possibility of rapid shutdown in the frames of certain startup site, for instance, in emergency cases or insufficient funding.

The main disadvantages of the variant are as follows:

- Necessity of embedment and vibration removal of numerous sheet piles;

- Necessity to mount numerous spacers.

Metal sheet piling was designed using Plaxis 2D software.

Plaxis 2D is a powerful and convenient finite element software package designed for 2D calculations of deformations and stability of construction objects. PLAXIS is used worldwide by leading civil and industrial engineering companies and institutes for the calculation of pits, embankments, foundations, tunnels, deposits and reservoirs. The program features a large set of functions for modeling various geotechnical tasks.

The geometry is modeled using standard types of structural elements and loads, using CAD-based drawing tools, which allows quickly and efficiently creating finite element models.

The Staged Construction mode allows simulating the construction process by activating and deactivating soil clusters and structural elements at each stage of the calculation. The proposed types of calculations (plastic calculation, consolidation calculation, dynamic and seepage analysis, stability calculation) allow using Plaxis for solving complex geotechnical problems. PLAXIS offers a variety of soil and rock behavior models (from simple linear models to advance nonlinear ones). Verified and robust iterative computational procedures are used. With multithreaded computing and a 64-bit computational core, Plaxis can operate with the largest and most complex models.

The Output program provides various ways to display forces, displacements, stresses, and flows in the form of contours, vectors, and tables. Cross sections may be used to investigate areas of interest. Results from tables can be copied to other applications for further processing. Using the Curve manager option, graphs of various types of results can be created at different stages of the calculation. Using Python scripting, results can be imported into other programs that support APIs. In order to provide minimum impact of construction activities on existing buildings and structures, the following engineering approaches were adopted: prior to excavation activities, the bases, foundations, and above-ground structures of buildings Nos. 11, 13, and 15 adjacent to the project site had to be reinforced; excavation shoring was made of sheet pooling. Sheet pile length was 24 $\mathrm{m}$. Sheet pile was not removable (except for certain internal sheet piles); excavation activities were performed using one or two rows of expanding metal structure made of pipes; prior to start of the construction, the piles for foundation reinforcement and main piles were tested, the sheet piling was embedded and pilot trench was excavated. These measures provided detailed data on impacts of embedment on adjacent territory. In the course of construction, settlements of surrounding territory and building were monitored, as well as vibrations and horizontal deviations of sheet piling (Rengach, 1970; Berendeev, 2009). 
International Journal of Mathematical, Engineering and Management Sciences

Vol. 5, No. 5, 897-912, 2020

https://doi.org/10.33889/IJMEMS.2020.5.5.069

2D flowcharts were used for solution of the considered problems. A series of predictions were performed using Plaxis 2D software; two variants were described in this article: excavation with the bottom elevation of $+0.560 \mathrm{~m}$ and excavation with the bottom elevation of $-2,500 \mathrm{~m}$ and adjacent building (at the distance of $2.5 \mathrm{~m}$ ).

The model was based on the Mohr-Coulomb theory which facilitated estimation of geotechnical environment.

\section{Results}

Prediction of excavation retaining wall at the bottom elevation of $+0.560 \mathrm{~m}$ was performed using Plaxis 2D software. Soil properties used in Plaxis 2D model are summarized in Table 1. Absolute surface elevation was $+6.000 \mathrm{~m}$.

Table 1. Soil properties of variant 1

\begin{tabular}{|c|c|c|c|c|c|c|c|c|}
\hline EGE & Description & $\begin{array}{c}\text { Absolute } \\
\text { bottom } \\
\text { elevation, } \mathrm{m}\end{array}$ & $\begin{array}{c}\text { Dry } \\
\text { density, } \\
\mathrm{kN} / \mathrm{m}^{2}\end{array}$ & $\begin{array}{c}\text { Bulk } \\
\text { density, } \\
\mathrm{kN} / \mathrm{m}^{2}\end{array}$ & $\begin{array}{l}\text { Cohesio } \\
\mathrm{n}, \mathrm{kPa}\end{array}$ & $\begin{array}{l}\text { Angle of } \\
\text { internal } \\
\text { friction, }\end{array}$ & $\begin{array}{l}\text { Deformation } \\
\text { modulus, } \\
\mathrm{kN} / \mathrm{m}^{2}\end{array}$ & $\begin{array}{l}\text { Poisson's } \\
\text { ratio }\end{array}$ \\
\hline 1 & Fill soils & +6.000 & 11.0 & 16.3 & 11 & 4 & 5,000 & 0.3 \\
\hline 2 & Silty loose sands & +4.500 & 13.2 & 17.8 & 1 & 23 & 5,000 & 0.3 \\
\hline 3 & Weakly peaty soils & +3.500 & 10.2 & 16.3 & 11.3 & 5 & 3,000 & 0.3 \\
\hline 4 & $\begin{array}{ll}\text { Silty sands of } \\
\text { medium density }\end{array}$ & +0.500 & 15.4 & 19.7 & 3 & 28 & 15,000 & 0.3 \\
\hline 5 & Plastic clay sands & -1.000 & 14.7 & 19.3 & 8 & 9 & 6,700 & 0.34 \\
\hline 6 & Fine dense sands & -3.000 & 17.0 & 20.7 & 3 & 35 & 38,000 & 0.3 \\
\hline 7 & $\begin{array}{l}\text { Fluid loams with very } \\
\text { soft interlayers }\end{array}$ & -4.000 & 14.9 & 19.4 & 6 & 8 & 6,000 & 0.37 \\
\hline 8 & $\begin{array}{l}\text { Fluid loams with very } \\
\text { soft interlayers, strip- } \\
\text { like }\end{array}$ & -10.000 & 1.29 & 18.2 & 6 & 3 & 5,000 & 0.37 \\
\hline 9 & $\begin{array}{l}\text { Very soft loams, } \\
\text { laminated }\end{array}$ & -13.500 & 14.5 & 19.1 & 6 & 7 & 8,000 & 0.37 \\
\hline 10 & $\begin{array}{l}\text { Plastic clay sands, } \\
\text { indistinctly laminated }\end{array}$ & -17.500 & 15.8 & 19.9 & 31 & 10 & 11,000 & 0.34 \\
\hline 11 & Sandy clay & -18.000 & 19.0 & 22.1 & 6 & 22 & 21,000 & 0.34 \\
\hline 12 & Silty dense sands & -24.500 & 17.5 & 21.0 & 7 & 33 & 34,000 & 0.3 \\
\hline 13 & $\begin{array}{l}\text { Plastic clay sands } \\
\text { with solid interlayers }\end{array}$ & -28.500 & 18.8 & 21.8 & 25 & 20 & 18,000 & 0.34 \\
\hline
\end{tabular}

One-level excavation is shored by Z-shaped sheet piles: AZ 42-700N. Its properties are as follows: cross section area $S=259 \mathrm{~cm}^{2} / \mathrm{m}$, wall weight $m=203 \mathrm{~kg} / \mathrm{m}^{2}$, moment of inertia $I=104,930 \mathrm{~cm}^{3} / \mathrm{m}$, elastic moment of resistance $W=4,205 \mathrm{~cm}^{3} / \mathrm{m}$, elasticity modulus $E=200,000 \mathrm{MPa}$.

Spacers are made of metal pipes $720 \times 10$ installed at the height of $+4.700 \mathrm{~m}$.

Figures 5-7 illustrate the predictions.

Prediction of retaining wall of complex excavation site at bottom elevation of $-2,500 \mathrm{~m}$ was performed using Plaxis 2D software. Soil properties used in Plaxis 2D model are summarized in Table 2. Absolute surface elevation was $+6.000 \mathrm{~m}$. 
International Journal of Mathematical, Engineering and Management Sciences

Vol. 5, No. 5, 897-912, 2020

https://doi.org/10.33889/IJMEMS.2020.5.5.069

In this case combination of sheet piles AU-14 and pipe piles $820 \times 10$ reinforced by double $\mathrm{T}$ beam $40 \mathrm{k} 5$ and filled with V20 concrete is used.

Sheet pile properties are as follows: cross section area $S=132 \mathrm{~cm}^{2} / \mathrm{m}$, wall weight $m=104 \mathrm{~kg} / \mathrm{m}^{2}$, moment of inertia $I=28,680 \mathrm{~cm}^{3} / \mathrm{m}$, elastic moment of resistance $W=1,405 \mathrm{~cm}^{3} / \mathrm{m}$, elasticity modulus $E=200,000 \mathrm{MPa}$.

Table 2. Soil properties for variant 2

\begin{tabular}{|c|l|c|c|c|c|c|c|c|}
\hline EGE & \multicolumn{1}{|c|}{ Description } & $\begin{array}{c}\text { Absolute } \\
\text { bottom } \\
\text { elevation, } \\
\mathrm{m}\end{array}$ & $\begin{array}{c}\text { Dry } \\
\mathrm{density,} \\
\mathrm{kN} / \mathrm{m}^{2}\end{array}$ & $\begin{array}{c}\text { Bulk } \\
\text { density, } \\
\mathrm{kN} / \mathrm{m}^{2}\end{array}$ & $\begin{array}{c}\text { Cohesion, } \\
\mathrm{kPa}\end{array}$ & $\begin{array}{c}\text { Angle of } \\
\text { internal } \\
\text { friction, }\end{array}$ & $\begin{array}{c}\text { Deformation } \\
\text { modulus, } \\
\mathrm{kN} / \mathrm{m}^{2}\end{array}$ & $\begin{array}{c}\text { Poisson's } \\
\text { ratio }\end{array}$ \\
\hline 1 & Fill soils & +6.000 & 11.0 & 16.3 & 11 & 4 & 5,000 & 0.3 \\
\hline 2 & Silty loose sands & +4.500 & 13.2 & 17.8 & 1 & 23 & 5,000 & 0.3 \\
\hline 3 & Weakly peaty soils & +3.000 & 10.2 & 16.3 & 11.3 & 5 & 3,000 & 0.3 \\
\hline 4 & $\begin{array}{l}\text { Silty sands of medium } \\
\text { density }\end{array}$ & +0.500 & 15.4 & 19.7 & 3 & 28 & 15,000 & 0.3 \\
\hline 5 & Plastic clay sands & -1.000 & 14.7 & 19.3 & 8 & 9 & 6,700 & 0.34 \\
\hline 6 & Fine dense sands & -2.000 & 17.0 & 20.7 & 3 & 35 & 38,000 & 0.3 \\
\hline 7 & $\begin{array}{l}\text { Fluid loams with Fluid } \\
\text { loams with very soft } \\
\text { interlayers }\end{array}$ & -3.000 & 14.9 & 19.4 & 6 & 8 & 6,000 & 0.37 \\
\hline 8 & $\begin{array}{l}\text { Fluid loams with very } \\
\text { soft interlayers, strip- } \\
\text { like }\end{array}$ & -6.000 & 1.29 & 18.2 & 6 & 3 & 5,000 & 0.37 \\
\hline 9 & Very soft loams, laminar & -9.000 & 14.5 & 19.1 & 6 & 7 & 8,000 & 0.37 \\
\hline 10 & $\begin{array}{l}\text { Plastic clay sands, } \\
\text { indistinctly laminated }\end{array}$ & -15.000 & 15.8 & 19.9 & 31 & 10 & 11,000 & 0.34 \\
\hline 11 & Sandy clay & -18.000 & 19.0 & 22.1 & 6 & 22 & 21,000 & 0.34 \\
\hline 12 & Silty dense sands & -23.000 & 17.5 & 21.0 & 7 & 33 & 34,000 & 0.3 \\
\hline 13 & $\begin{array}{l}\text { Plastic clay sands with } \\
\text { solid interlayers }\end{array}$ & -30.000 & 18.8 & 21.8 & 25 & 20 & 18,000 & 0.34 \\
\hline
\end{tabular}

Properties of composite steel concrete pile are as follows: cross section area $S=5,278 \mathrm{~cm}^{2} / \mathrm{m}$, wall weight $m=1,248 \mathrm{~kg} / \mathrm{m}^{2}$, axial stiffness $E A=20,790,262 \mathrm{kN} / \mathrm{m}^{2}$, bending stiffness $E I=1,046,064$ $\mathrm{kN} / \mathrm{m}^{2}$.

Spacers are made of metal pipes $720 \times 10$, their first row is installed at the height of $+4.700 \mathrm{~m}$, the second - at the height of $+2.250 \mathrm{~m}$.

This problem was solved in Plaxis in the form of two plates positioned at minimum distance from each other with interspace filled with elastic soil which transferred load from one plate to another. Figures 8-10 illustrate the predictions. 
International Journal of Mathematical, Engineering and Management Sciences

Vol. 5, No. 5, 897-912, 2020

https://doi.org/10.33889/IJMEMS.2020.5.5.069
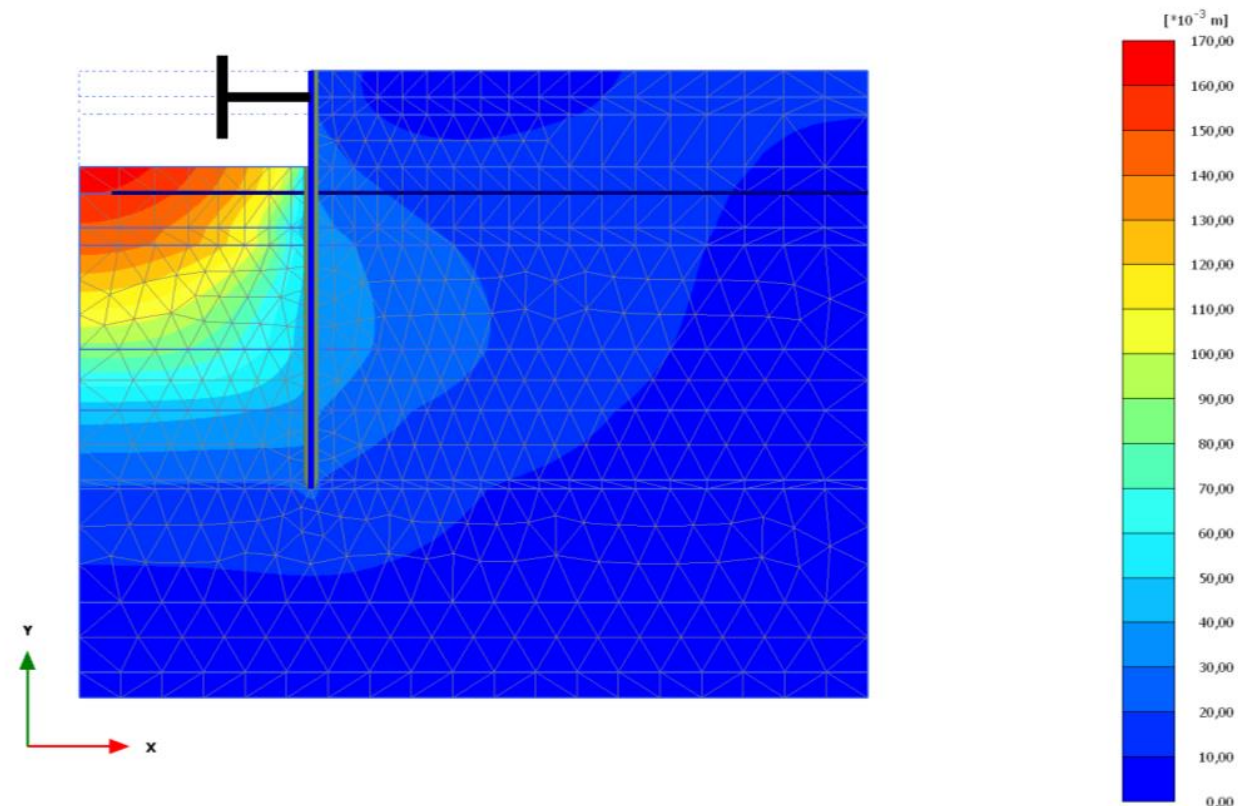

Total displacements $|\mathbf{u}|$

Maximum value $=0,1661 \mathrm{~m}$ (Element 546 at Node 209)

Figure 5. Total displacements

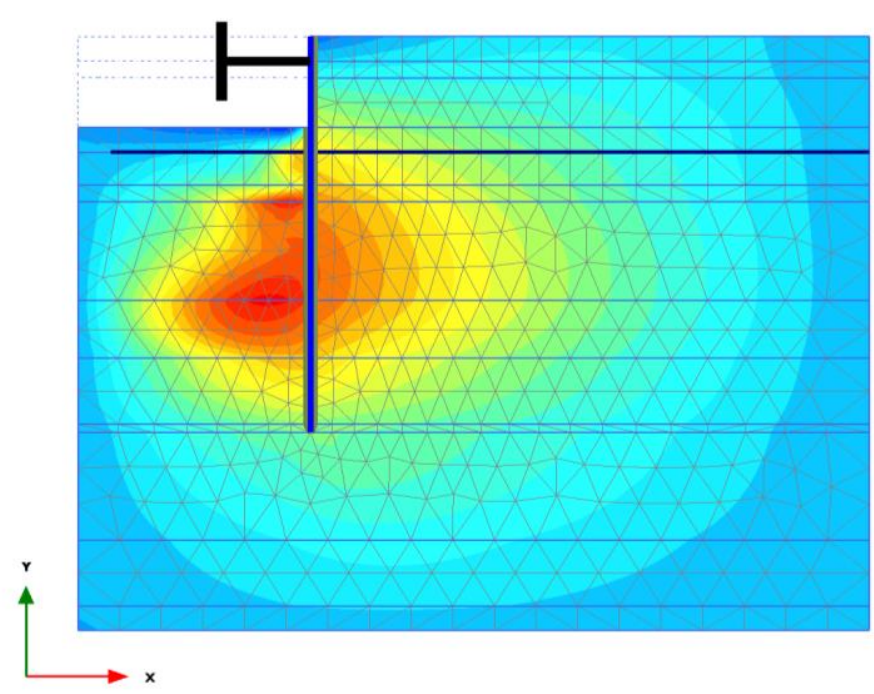

Total displacements $\mathbf{u}_{\mathbf{x}}$

Maximum value $=0,01020 \mathrm{~m}$ (Element 539 at Node 802)

Minimum value $=-0,03853 \mathrm{~m}$ (Element 310 at Node 555)

Figure 6. Displacement profile along $\mathrm{X}$ axis 
International Journal of Mathematical, Engineering and Management Sciences

Vol. 5, No. 5, 897-912, 2020

https://doi.org/10.33889/IJMEMS.2020.5.5.069

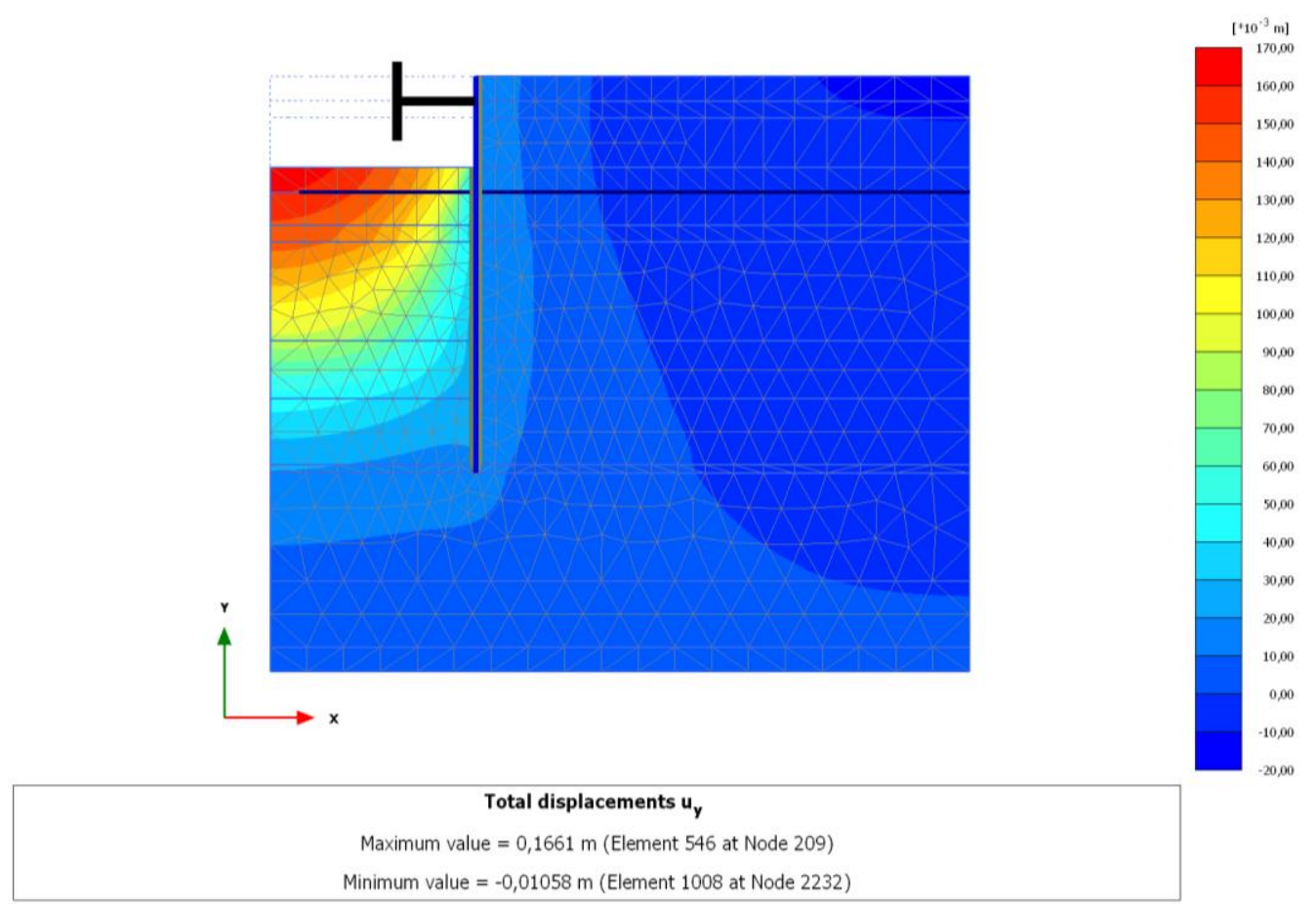

Figure 7. Displacement profile along Y axis
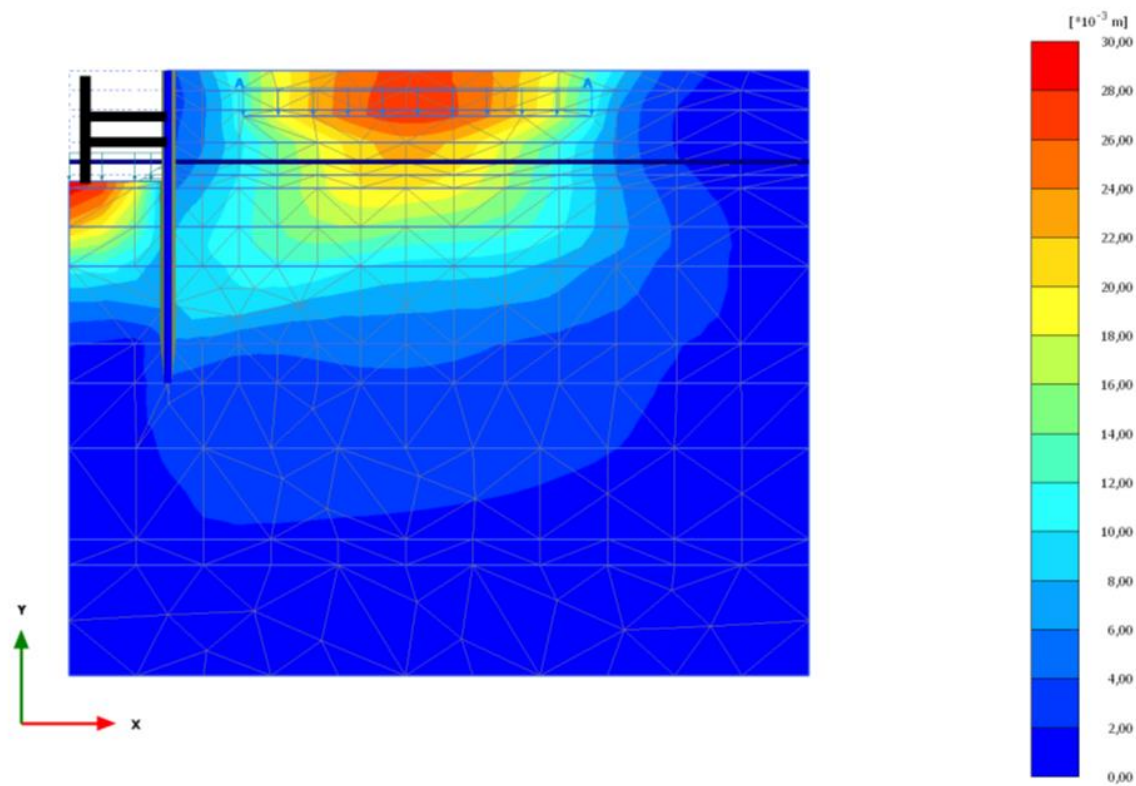

Total displacements | u

Maximum value $=0,02938 \mathrm{~m}$ (Element 222 at Node 121)

Figure 8. Total displacements 
International Journal of Mathematical, Engineering and Management Sciences

Vol. 5, No. 5, 897-912, 2020

https://doi.org/10.33889/IJMEMS.2020.5.5.069
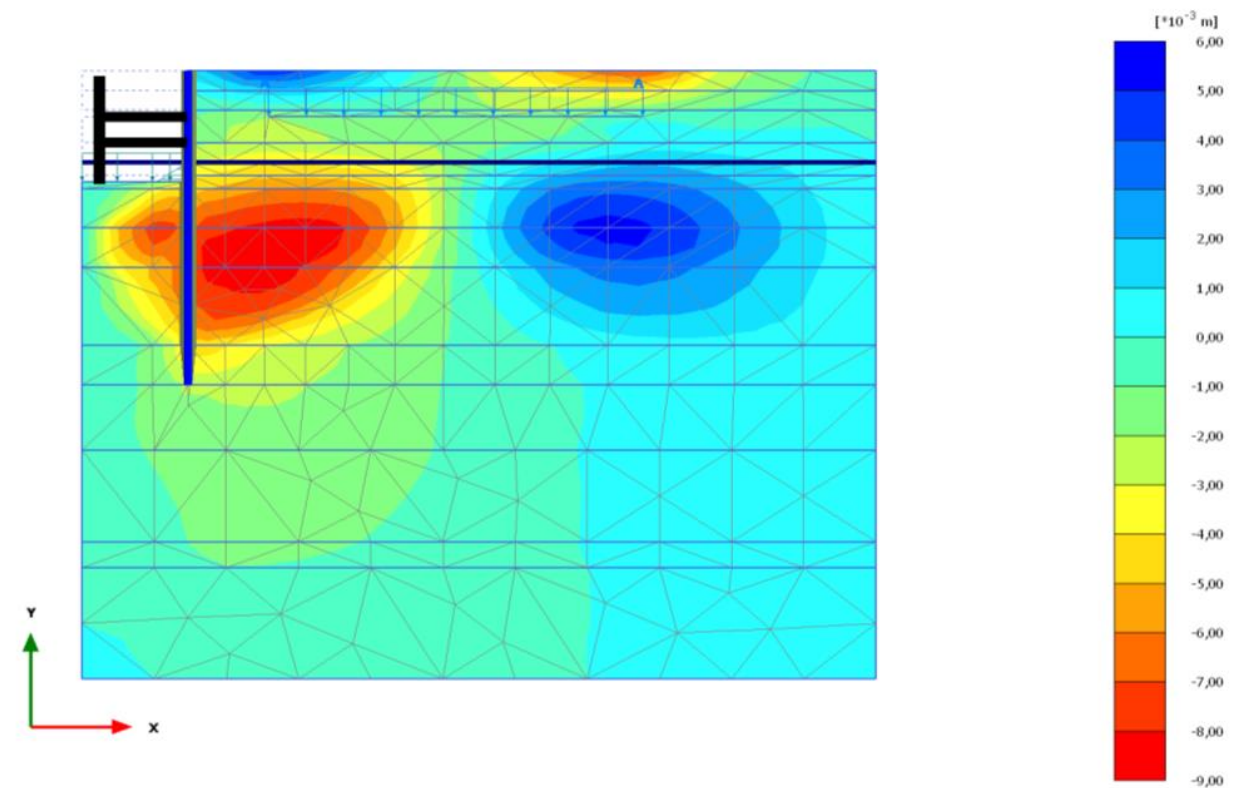

\begin{tabular}{|c|}
\hline Total displacements $\mathbf{u}_{\mathbf{x}}$ \\
\begin{tabular}{|c|} 
Maximum value $=0,005482 \mathrm{~m}$ (Element 248 at Node 943) \\
Minimum value $=-0,008971 \mathrm{~m}$ (Element 236 at Node 601)
\end{tabular} \\
\hline
\end{tabular}

Figure 9. Total displacements along $\mathrm{X}$ axis

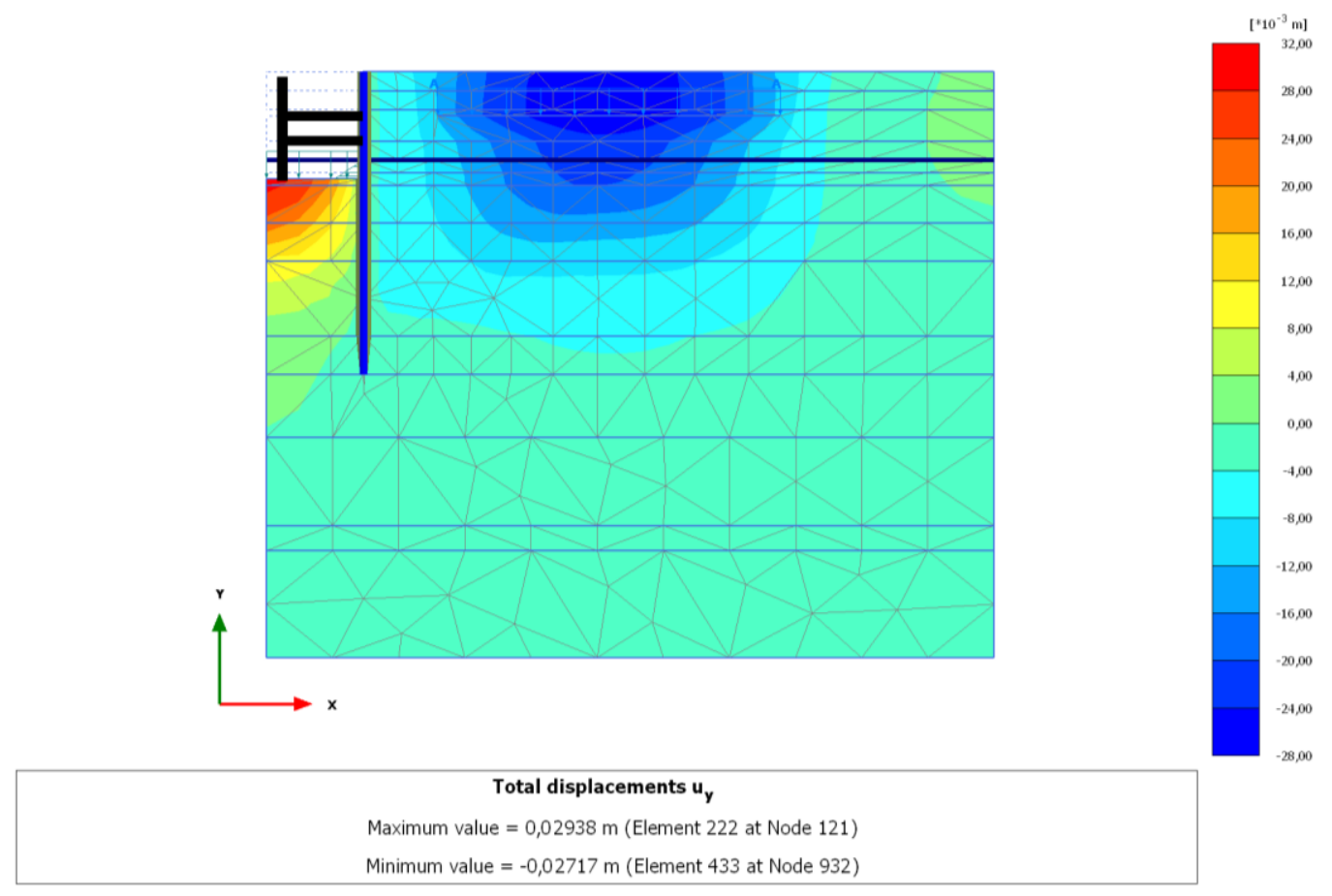

Figure 10. Total displacements along $\mathrm{Y}$ axis 
International Journal of Mathematical, Engineering and Management Sciences

Vol. 5, No. 5, 897-912, 2020

https://doi.org/10.33889/IJMEMS.2020.5.5.069

\section{Discussion}

Predictions of excavation retaining wall according to variant 1 have demonstrated that horizontal displacements of sheet piling are $12 \mathrm{~mm}$. In addition, soil is moved upwards at the bottom by 166 $\mathrm{mm}$, which can be attributed to poor mechanical properties of soils (Tables 1-2).

Soil deformation occurs mainly in the active zone, behind the retaining wall, and only its small values are noted below the level of the pit bottom. It is known that the stiffness of the soil with small deformations is much higher than with the large ones. Accordingly, soil below the pit bottom has higher stiffness parameters than soil above the pit bottom.

The movement of the sheet pile occurs due to insufficient bending stiffness and an increase in the pressure of weak soil on the sheet pile after shear zone increase.

Maximum soil settlement near excavation pit is $20 \mathrm{~mm}$, which conforms the specifications. Predictions according to variant 2 show that horizontal displacements of the wall are $6 \mathrm{~mm}$. In addition, soil is moved upwards at the bottom by $32 \mathrm{~mm}$. The maximum additional settlement of building located at $2 \mathrm{~m}$ from the excavation is $30 \mathrm{~mm}$, which conforms the specifications.

Sheet piles are made of metal rolled profiles varying by shape of traversal cross section, lock design and its position with respect to the profile. Metal rolled profiles are characterized by moderate width and relatively high moment of resistance with regard to cross section area. Lock design in the form of hook or can provides simple installation of sheet pile for locking, required strength, tight connection of sheet piles between themselves. Foreign and domestic experience of the use of metal sheet piling made it possible to reveal areas of their efficient application as permanent elements of underground buildings and structures (subsurface and partially-in-ground). The application fields of shaped steel sheet piles as permanent structural elements cover all spheres of construction activities. Conventionally sheet piles are used for erection of hydrotechnical facilities upon construction of mooring, ports, etc. (Klein and Cherkasov, 1985; Konyukhov, 2005; Kovshov and Skamyin, 2017; Carranza et al., 2018; Zambrano et al., 2018)

In recent decade steel sheet piles have been widely applied in rod construction (automobile and railroad) as shoring of tunnels, overhead crossings, embankments and the like; moreover, wide experience has been gained in the field of application of sheet piles in civil and industrial construction as retaining walls, shoring of excavations, trenches, mines and as cutoff curtains upon construction of underground parking lots, technical, sales, entertainment, and sporting rooms.

It should be mentioned that prior to submersion of sheet piles, it is necessary to check the following parameters: to check certificates for sheet piles; to examine visually curvature of sheet pile, state of locks, linear dimensions, state of metal. During submersion of sheet piles, it is necessary to check the following parameters: speed of submersion; during submersion of initial sheet piles (or packages), it is required to pay attention to their strictly vertical direction which is verified by tilt sensor in two planes. Vertical direction of sheet piles in two planes should be verified for each five sections of sheet piles. It is required to take measures preventing deviation of sheet pile from designed position in excess of specifications (Benderev, 2008; Benderev, 2011). 
International Journal of Mathematical, Engineering and Management Sciences

Vol. 5, No. 5, 897-912, 2020

https://doi.org/10.33889/IJMEMS.2020.5.5.069

\section{Conclusions}

It should be mentioned that nowadays, upon global growth of megalopolises, even slight error in designing or construction of underground garages in the frames of greenfield projects or retrofitting of existing buildings can lead to destruction of remaining monuments of architecture as well as to rehousing of residents.

In order to provide reliability and safety of remaining monuments of architecture during construction of underground garages, as well as safety of neighboring structures which can be affected by the construction or retrofitting activities, it is required to provide integrated geotechnical assistance. Taking into account complex and multifactorial problems of geotechnical assistance, it is possible to achieve solution only by modern numerical methods based on physical and geomechanical nonlinear models.

The presented results are practical and can be applied by companies involved in designing and construction of underground garages in complex engineering and geological environment as well as performing monitoring of structures.

\section{Conflict of Interest}

The authors confirm that there is no conflict of interest to declare for this publication.

\section{Acknowledgement}

I express gratitude to my colleagues from the Department of Construction mining enterprises and underground facilities of St. Petersburg Mining University for their help and support in writing this article.

\section{References}

Abelev, M.Yu., \& Tokin, A.N. (1988). Osnovaniya i fundamenty iz ukreplennykh gruntov [Bases and foundations of reinforced soils]. Textbook. Moscow: Tsmipks.

Benderev, A.I. (2008). Ustroistvo ograzhdenii glubokikh kotlovanov iz shpunta v usloviyakh plotnoi gorodskoi zastroiki [Sheet piling for deep excavations in constrained urban environment]. Arkhitektura. Restavratsiya. Dizain. Stroitel'stvo, 4.

Benderev, A.I. (2011). Stal'nye shpunty AlcelorMittal dlya nadezhnosti podzemnykh parkingov [AlcelorMittal steel sheet piling for reliability of underground parking lots]. Stroitel'stvo I Gorodskoe Khozyaistvo Sankt-Peterburga I Leningradskoi Oblasti, 125.

Berendeev, A. (2009). Alcelor sheet piling: quality guarantee of underground structures. St Petersburg Construction Market, 11(112), 40-41.

Carayannis, E., Cherepovitsyn, A., \& Ilinova, A. (2017). Sustainable development of the russian arctic zone energy shelf: the role of the quintuple innovation helix model. Journal of the Knowledge Economy, 8(2), 456-470.

Carranza, J.R.Z., Kovshov, S., \& Lyubin, E. (2018). Assessment of anthropogenic factor of accident risk on the main oil pipeline Pascuales-Cuenca in Ecuador. Journal of Applied Engineering Science, 16(3), 307312. 
International Journal of Mathematical, Engineering and Management Sciences

Vol. 5, No. 5, 897-912, 2020

https://doi.org/10.33889/IJMEMS.2020.5.5.069

Cherepovitsyn, A., \& Ilinova, A. (2018). Methods and tools of scenario planning in areas of natural resources management. European Research Studies Journal, 21(1), 434-446.

Cherepovitsyn, A., Ilinova, A., \& Smirnova, N. (2017). Key stakeholders in the development of transboundary hydrocarbon deposits: the interaction potential and the degree of influence. Academy of Strategic Management Journal, 16 (S2).

Dalmatov, B.I. (1988). Mekhanika gruntov, osnovaniya i fundamenty (vklyuchaya spetsial'nyy kurs inzhenernoy geologii) [Soil mechanics, bases, and foundations (including special course in engineering geology)]. Leningrad: Stroyizdat.

Dashko, R.E., \& Lange, I.Yu. (2015). Prognozirovanie izmeneniya nesushchei sposobnosti peschanoglinistykh gruntov $\mathrm{v}$ protsesse ikh kontaminatsii nefteproduktami [Forecasting variations of bearing capacity of sand and clay soils in the course of their contamination with petroleum products]. Zapiski Gornogo Instituta, 211, 16-21.

Dashko, R.E., \& Lange, I.Yu. (2017). Engineering-geological aspects of negative consequences of contamination of dispersive soils by petroleum products. Zapiski Gornogo Instituta, 228, 624-630. Doi: 10.25515/PMI.20176.624.

Dashko, R.E., Aleksandrova, O.Yu., Kotyukov, P.V., \& Shidlovskaya, A.V. (2011). Osobennosti inzhenerno-geologicheskikh usloviy Sankt-Peterburga [Features of the engineering and geological conditions of St. Petersburg]. Razvitie Gorodov I Geotekhnicheskoe Stroitel'stvo [Urban development and geotechnical construction], 13, 25-71.

Gotman, Yu.A. (2011). Opredelenie optimal'nykh razmerov gruntotsementnogo massiva, snizhayushchego peremeshcheniya ograzhdeniy glubokikh kotlovanov [Determination of the optimal sizes of a soil-cement massif which reduces displacements of deep excavation shoring]. PhD thesis. Moscow state University of railway engineering, Moscow.

Ilichev, V.A., Gotman, Yu, A., \& Nazarov, V.P. (2009). Raschetnoe obosnovanie tekhnologii jet-grouting dlya snizheniya dopolnitel'nykh osadok sushchestvuyushchego zdaniya pri stroitel'stve podzemnogo kompleksa [Substantiation of jet-grouting technology aiming at reduction of additional sediment of existing building upon construction of underground complex]. Vestnik Grazhdanskikh Inzhenerov, 2, 9598.

Kazanin, O.I., Klimov, V.V., Alekseev, V.Y., \& Sidorenko, A.A. (2019a). Improvement of a longwall recovery room erection technology. International Journal of Civil Engineering and Technology, 10(2), 1148-1153.

Kazanin, O.I., Sidorenko, A.A., \& Sirenko, Y.G. (2019b). Analysis of the methods of calculating the main roof caving increment in mining shallow coal seams with long breaking faces. ARPN Journal of Engineering and Applied Sciences, 14(3), 732-736.

Klein, G.K., \& Cherkasov, I.I. (1985). Fundamenty gorodskikh transportnykh sooruzhenii [Foundations of municipal transport facilities]. Moscow: Transport.

Konyukhov, D.S. (2005). Stroitel'stvo gorodskikh podzemnykh sooruzhenii melkogo zalozheniya. Spetsial'nye raboty [Construction of urban subsurface facilities. Specialized activities]. Moscow: Arkhitektura-S.

Kovshov, S.V., \& Skamyin, A.N. (2017). Treatment of agricultural wastes with biogas-vermitechnology. Environmental Earth Sciences, 76(19), 660. Doi: 10.1007/s12665-017-7018-6.

Rengach, V.N. (1970). Shpuntovye stenki (Raschet i proektirovanie) [Piling walls: analysis and design]. Leningrad: Izdatel'stvo literatury po stroitel'stvu. 
International Journal of Mathematical, Engineering and Management Sciences

Vol. 5, No. 5, 897-912, 2020

https://doi.org/10.33889/IJMEMS.2020.5.5.069

Sidorenko, A.A., Ivanov, V.V., \& Sidorenko, S.A. (2019). Numerical simulation of rock massif stress state at normal fault at underground longwall coal mining. International Journal of Civil Engineering and Technology, 10(1), 844-851.

Zambrano, J., Kovshov, S., Lyubin, E., Martín, M.C., \& Segovia, J.J. (2018). Characterization of an Ecuadorian crude using a vibrating-tube densimeter and a vibrating-wire viscometer. Petroleum Science and Technology, 36(24), 2077-2083. 